\title{
SALT AND DROUGHT EFFECT ON GERMINATION AND INITIAL GROWTH OF Lavandula stoechas: A POTENTIAL CANDIDATE FOR REHABILITATION OF THE MEDITERRANEAN DISTURBED COASTAL LANDS
}

\author{
MOHAMMED DADACH $\varpi^{1}$, ALI BENAJAOUD ${ }^{2}$, ZOHEIR MEHDADI ${ }^{3}$ \\ ${ }^{1}$ Research Laboratory in Ecology and Environment, Faculty of Nature and Life Sciences, Bejaia University, Bejaia 06000, Algeria; e-mail: mohammed.dadach@ \\ univ-bejaia.dz, dadach_mohamed@yahoo.fr \\ ${ }^{2}$ Common core department, Faculty of Nature and Life Sciences, Bejaia University, Bejaia 06000, Algeria; e-mail: alibenadjaoud@yahoo.fr \\ ${ }^{3}$ Laboratory of Plant Biodiversity: Conservation and Valorization, Faculty of Natural Sciences and Life, Djillali Liabes University, Sidi Bel Abbes 22000, Algeria \\ e-mail: mehdadiz@yahoo.fr
}

$\triangle$ Corresponding author

Received: 12 April 2021 / Accepted: 8 July 2021

\begin{abstract}
Dadach M., Benajaoud A., Mehdadi Z.: Salt and drought effect on germination and initial growth of Lavandula stoechas: a potential candidate for rehabilitation of the Mediterranean disturbed coastal lands. Ekológia (Bratislava), Vol. 40, No. 4, p. 301-311, 2021.

Information relating to germination and seedling emergence of a plant aids in determining the species spatiotemporal distribution and also facilitates in designing appropriate plant management strategies within an ecosystem. Lavandula stoechas L. (Lamiaceae), a naturally occurring shrub, is particularly used in pharmaceutical and cosmetic industries. This species, indeed, has the potential for rehabilitation of degraded costal lands. However, various aspects of its seed biology have not yet been recognised. Here, we aimed to assess the effects of different soluble salts $\left(\mathrm{NaCl}_{2} \mathrm{CaCl}_{2}, \mathrm{MgCl}_{2}\right.$ and $\left.\mathrm{Na}_{2} \mathrm{SO}_{4}\right)$ and drought (as simulated by polyethylene glycol, $\left.[\mathrm{PEG}]_{6000}\right)$ on seed germination patterns and early seedling growth responses. Seeds treated with five iso-concentration (0-100 mM) salinities and five $\mathrm{PEG}_{6000}(0$ to $-1 \mathrm{MPa})$ levels were incubated in a controlled germinator set at $20^{\circ} \mathrm{C}$. The preliminary results revealed that seeds of $L$. stoechas lacked primary/innate dormancy and they germinated abundantly $\left(89.2 \%\right.$ germination) and fast $\left(7.4 \%\right.$ day $\left.{ }^{1}\right)$ in the absence of stress. Regardless of the kind of salt applied, the germination percentage (GP) and germination rate index (GRI) fell significantly with increasing salinity, and germination ceased completely at $100 \mathrm{mM} \mathrm{Na}_{2} \mathrm{SO}_{4}$. In fact, the salinity tolerance index (STI) showed that, among all salts tested, $\mathrm{Na}_{2} \mathrm{SO}_{4}$ appeared to have more inhibitory action on germination In addition, $L$. stoechas was found to be tolerant to moderate salty stress $(<50 \mathrm{mM})$ in early growth phase. The salt solution parameters (i.e. concentration, electrical conductivity $[\mathrm{EC}]$ and salt content) were best correlated with seed/seedling metrics. $\mathrm{pH}$ was not a good predictor for salt effects at the germination/seedling stages. Overall, this species seems to be sensitive to drought at the germination and initial growth phases. The germination recovery potential of $L$. stoechas in both stresses stipulates that this species can be regarded as a promising candidate in the rehabilitation of Mediterranean disturbed coastal habitats.
\end{abstract}

Key words: Lavandula stoechas, salt stress, water stress, germination patterns, seedling growth.

\section{Introduction}

The Mediterranean ecosystem is currently undergoing indubitably advanced degradation, as compared to other regions around the world, already exacerbated by substrate salinisation, prolonged drought, land clearing and plant overexploitation (Cherifi et al., 2017; Sardans et al., 2020). These threats are causing multiple negative impacts on the Mediterranean coastal habitat vegetation in the form of low emergence of new seedlings, limitation of plant population distribution, shift in phenology and reproduction timing (Belgacem et al., 2008). Critically, rehabilitation of these habitats is often barely feasible due to soil salinity, sporadic rainfall patterns and rough topography (Martínez-Valderrama et al., 2018). Under such circumstances, various attempts in management practices have been implemented, including ecosystem resilience and afforestation programmes with which native plants are utilised, and some of these attempts, fortunately, have shown promising results particularly under desirable climatic conditions (Nedjimi, 2012).

Seed germination and early seedling growth, being the most fragile and vulnerable phases in plant life cycle, are intimately connected and closely effected by various overlapping environmental factors such as temperature, water availability, soil salinity and light, thereby seedling establishment requirements are the bottleneck that should be framed, whether for the crop production or land restoration (Zhang et al., 2018; Paraskevopoulou et al., 2020). For example, soil salinity could disturb directly plant plasticity via the harmful effects of excessive ion accumulation (i.e. ion toxicity) or indirectly through osmosis by obstructing plant imbibition by water (Tuteja, 2007), and thus, both circumstances lead to an oxidative stress and severe impairment in germination and plant growth (De Souza et al., 2016).

High salinization rate is the most pernicious stress factor facing soils, which leads to restriction in plant distribution and

(c) The Author(s) 2021. This is an open access article distributed under the terms of the CC BY-NC-ND license.

https://content.sciendo.com/view/journals/eko/eko-overview.xml 
productivity (Farooq et al., 2017). Affecting 20\% of irrigated lands and $7 \%$ of the earth's land surface, this widespread threat is often owing to either excessive evaporation induced by aridity, intensive use of brackish groundwater, seawater intrusion or soil-unsustainable practices (Machado, Serralheiro, 2017; Alfarrah, Walraevens, 2018). To investigate the effect of salt on germination and seedling growth, various studies have conventionally used sodium chloride $(\mathrm{NaCl})$, since it is the most preponderant salt contained in soils (El-Keblawy, Al-Rawai, 2005; Mehdadi et al., 2017). Moreover, in addition to $\mathrm{Na}^{+}$and $\mathrm{Cl}^{-}$, there are many other cations (e.g. $\mathrm{Mg}^{2+}, \mathrm{Ca}^{2+}, \mathrm{K}^{+}$) and anions (e.g. $\mathrm{SO}_{4}{ }^{2-}, \mathrm{HCO}_{3}^{-}$, $\mathrm{CO}_{3}{ }^{2-}$ ) held in salty soils (Qadir et al., 2000). These inorganic ions can either act in soil as osmoticum and restrict plant emergence (Sosa et al., 2005) or cause toxic effect and inflect embryo mortality (Llanes et al., 2005). Sosa et al. (2005) suggested that salt ion effects would have less influence on seed germination in Prosopis strombulifera than the soil water content. Comparable constatations were also drawn on the seed germination of Chenopodium glaucum (Duan et al., 2004), Suaeda vermiculata (ElKeblawy et al., 2018), Haloxylon stocksii (Rasheed et al., 2019) and Prosopis pallida (Aljasm et al., 2021). Zehra et al. (2013) reported the germination inhibition in Phragmites karka by using different salts of sodium, magnesium and potassium. They postulated that if such seeds did not recover, the mortality may be due to specific ion injury.

Mediterranean soils are not only affected by $\mathrm{NaCl}$, but also by other saline agents (e.g. $\mathrm{MgCl}_{2}, \mathrm{CaCl}_{2}$ and $\mathrm{Na}_{2} \mathrm{SO}_{4}$ ). In many cases, these are present at higher doses than $\mathrm{NaCl}$ (Alexakis et al., 2015; Nedjimi et al., 2020); each of them affects seed germination and plant emergence in distinct ways (Li et al., 2010). Testing the influence of multiple salt agents on seed germination and seedling growth not only sheds light into plant tolerance under these salts, but also helps in extrapolating the results from laboratory to natural conditions with increased reliability (Zhang et al., 2018). A large number of studies have mainly focused on the impact of soluble salts on germination, distribution, exploitation and physiological resistance mechanisms in halophytes (i.e. salttolerant plants) (Zhang et al., 2015; Zhao et al., 2014). However, there are much less investigations highlighting the influence of these salts upon seed germination and plant growth of glycophytes (i.e. salt-sensitive plants) (Nedjimi, Zemmiri, 2019).

In high-salty habitats, the plants can suffer a break in cells' ion homeostasis, disturbance in ionic balance, inhibition in enzyme activity and severe restraint in the distribution of $\mathrm{K}^{+}$and $\mathrm{Ca}^{2+}$ in cells (Niu et al., 1995). In such an environment, plants can tolerate the influence of stress only if they can adjust their osmotic pressure and restore their ionic balance (Li et al., 2011). In barley (Hordeum vulgare L.), maintenance of high germination under salt stress necessitated (1) synthesis of organic solutes that conferred to seeds an osmotic adjustment and facilitated seed water imbibition and (2) compartmentalisation of $\mathrm{Na}^{+}$in the vacuole, thereby countering the toxic effects of $\mathrm{Na}^{+}$on the cell (Zhang et al., 2010). Khan and Gulzar (2003) postulated that in coastal lands, generally suffering rising salinity levels, the increase in relative humidity substantially dilutes the salt concentration in soil. They further suggested that, to enhance the prospects of successful recovery of coastal land, assessing plant tolerance against salt stress during germination is critical prior to planning such projects.

In nature, drought is the most common and lethal stress for plants, particularly in critical growth stages, and it may result in complete cessation of plant development (Hossain et al., 2016). Besides, several approaches in the climate change scenarios forecast an outstanding increase in water shortage associated with more frequent, prolonged and intense droughts in many regions around the world (Zhang et al., 1999). In the Mediterranean region, aridity has deleterious repercussions on plant physiology. Indeed, water deficit leads to a decrease in soil water potential that prevents and delays plant emergence (Krichen et al., 2014; Dadach, Mehdadi, 2018). Owing to these concerns, considerable efforts were undertaken in the hope of deciphering mechanisms underlying plant responses to water stress, with the objective to breed resistant crops. Wild plants, meanwhile, deploy a number of adaptive mechanisms to cope with aridity. Postponing germination till the arrival of adequate conditions, including sufficient rainfall, is one such mechanism (Aljasmi et al., 2021). Till date, little is known about seed germination performance and plant growth response against drought, particularly in the North African natural flora (Dadach, Mehdadi, 2021). Understanding the level of moisture stimulating germination and species-specific threshold tolerance to water stress is the cornerstone towards achieving sustainable plant reintroduction and land restoration projects in degraded habitats (De Carvalho et al., 2020; Aljasmi et al., 2021).

Lavandula stoechas (Lamiaceae) is a well-known multipurpose plant that is often used throughout the Mediterranean region in traditional medicine, perfumes and other personal care products or sold as an ornamental plant for gardening (Ernst, 2017). Lavender is distributed over North Africa, the Mediterranean basin, Europe and western India. This species is found naturally growing in the coastal shrub lands, coastal garrigues and sea cliffs, often exposed to sea spray (Paraskevopoulou et al., 2020). It is commercially cultivated worldwide in a number of countries mainly in Europe and Asia (Shawl, Kumar, 2000; Lawrence, 2008). In controlled conditions, optimum temperature for germination of $L$. stoechas seeds is $20^{\circ} \mathrm{C}$ (Catav et al., 2012). Previously, many assays were done for the domestication of lavender in India during the British period. Later, in 2000, the Institute of Himalayan Bioresource successfully introduced this shrub in Himachal Pradesh, India (Singh et al., 2007).

Several phytopharmacological reports have emphasised that $L$. stoechas has the potential to treat nephrotic syndromes and rheumatic diseases, acts as an antispasmodic agent, and reduces the level of hyperglycemia, pain and inflammatory problems (Benabdelkader et al., 2011; Ez zoubi et al., 2016). Many essential oils extracted from $L$. stoechas leaves have shown effective antibacterial and antiviral activities. For example, camphor and 1,8-cineole have an antibacterial effect, mainly against Escherichia coli, Listeria monocytogenes and Staphylococcus aureus (Sarac, Ugur, 2009). Recently, El Ouali et al. (2016) inferred that Lavandula stoechas essential oils have a positive effect against Anopheles labranchiae, a malaria transmission vector, at a dose of $500 \mathrm{mg} \mathrm{ml}^{-1}$. These essential oils are often obtained either by infusion or from the decoction of leaves or the whole aerial part (Ez zoubi et al., 2020).

Taking the above into account and considering the lack of data on the effect of salinity and water stress on Lavandula stoechas seed germination and growth, and in the context to carry out restoration of the Algerian disturbed coastal habitats, characterised by high salt influence and unpredictable precipitation, 
this work was conducted in an attempt to highlight the effects of different salt agents (mostly encountered in these lands) and drought on seed germination patterns and early growth parameters in this valuable species. The results would also provide more insight about the effectiveness of L. stoechas regeneration through seeds under the most common abiotic stresses affecting the Mediterranean ecosystem.

\section{Material and methods}

\section{Study species and seed harvesting site}

Butterfly lavender (L. stoechas), also named toupee lavender or wild lavender (Boukhatem et al., 2020), is a perennial, evergreen, low-growing shrub (chamaephyte) that usually grows to $0.3-1$ $\mathrm{m}$ in height, with erect, quadrangular and floriferous stems that become woody and rough on ageing. The flowers are pink to purple, having pedicel and tubular calyx and arranged in whorls tied in dense cylindrical clusters up to $5 \mathrm{~cm}$ long. Each flower is subtended by a bract $4-8 \mathrm{~mm}$ long. Leaves are opposite, sessile, 1-4 cm long, greyish and tomentose (covered with dense small hairs) with a strong aromatic odour (Fig. 1). L. stoechas starts flowering in late winter and it reaches the full bloom from mid-June to mid-July (Quézel, Santa, 1963; Ez zoubi et al., 2020). Fruit is an achene that is woody, brown and dehiscent containing four blackish-brown subglobose seeds (Lim, 2014). This species grows in rocky, calcareous areas and prefers acidic soils, but it can thrive in clay soils $(\mathrm{pH}>8.5)$.

Ripe inflorescences, containing L. stoechas mature seeds, were collected in August 2020 from a wild-growing population in the vicinity of Bejaia city, Northeast Algeria $\left(36^{\circ} 44^{\prime} \mathrm{N}, 05^{\circ} 01^{\prime} \mathrm{E}\right)$. The seed-harvesting site has a typical Mediterranean climate, where precipitation is less than $800 \mathrm{~mm}$ per annum, with extreme heterogeneity in time, most of the rains occurring in winter, and an average temperature of about $19.5^{\circ} \mathrm{C}$. The soil is non-saline, with an electrical conductivity (EC) of $0.55 \mathrm{mS} \mathrm{cm}^{-1}$, and slightly alkaline $(\mathrm{pH}=7.8)$. Seeds were randomly collected from almost a whole population ( $>60$ plants) in order to avoid genetic homogeneity. The associated plants with $L$. stoechas are garrigue characteristic species such as Scabiosa columbaria, Galactites tomentosa, Echium creticum, Myrtus communis, Genista tinctoria and Cistus monspeliensis. Once at laboratory, the mature seeds were peeled by hand from achenes-pericarp and kept at ambient temperature till the experiment was conducted.

\section{Seed germination experiment}

Before being used for tests, healthy and intact seeds were surface sterilised by hypochlorite solution $(10 \% \mathrm{NaOCl})$ for $5 \mathrm{~min}$ and washed abundantly with distilled water. In order to assess the impact of various salt agents $\left(\mathrm{NaCl}, \mathrm{CaCl}_{2}, \mathrm{MgCl}_{2}\right.$ and $\left.\mathrm{Na}_{2} \mathrm{SO}_{4}\right)$ and drought upon the germination pattern and initial seedling growth in Lavandula stoechas, seeds were germinated at five salt $(0,25,50,75$ and $100 \mathrm{mM})$ iso-concentrations and five polyethylene glycol (PEG) ${ }_{6000}(0,-0.25,-0.5,-0.75$ and $-1 \mathrm{MPa})$ levels. The EC and $\mathrm{pH}$ of all salt solutions as well as the salt content of each solution are given in Table 1 . EC and $\mathrm{pH}$ were measured by WTW Multi 9310 instrument at $20 \pm 1{ }^{\circ} \mathrm{C}$ (the same germination $\mathrm{T}^{\circ}$ ). PEG solutions were obtained by dissolving different

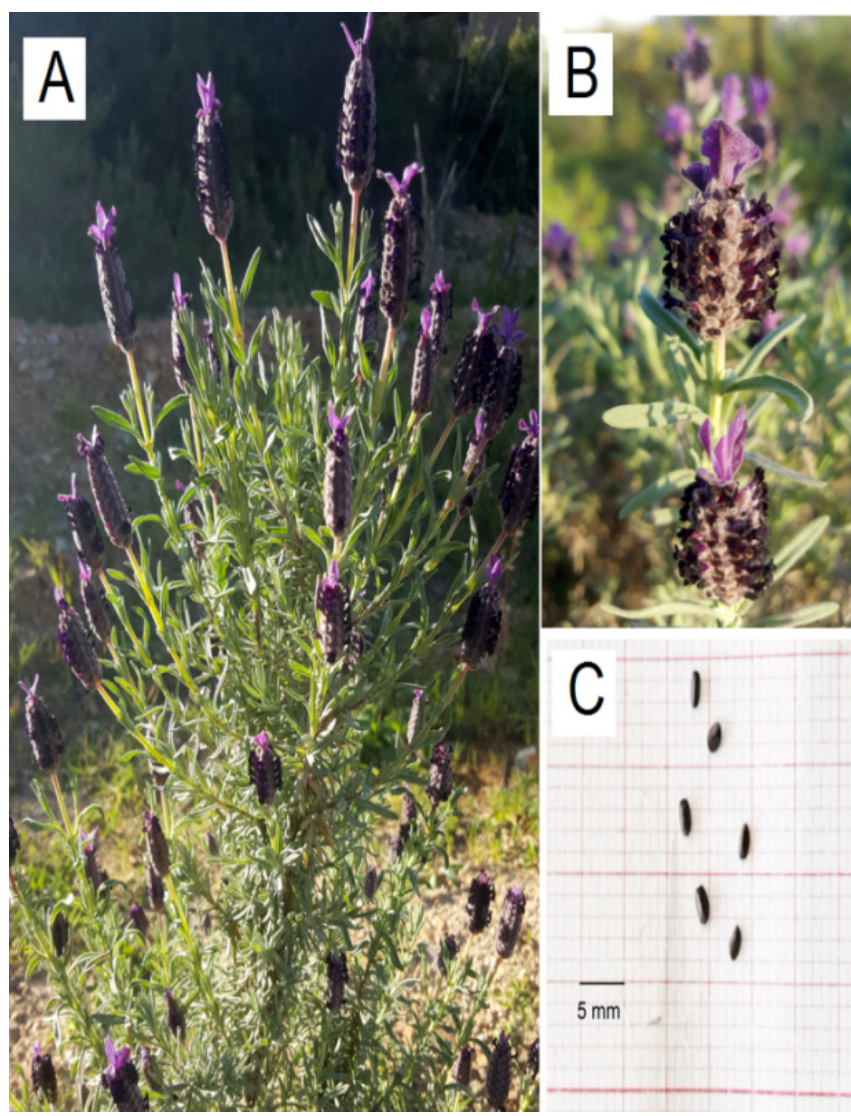

Fig. 1. Butterfly lavender (Lavandula stoechas) aerial part (A), flower cluster (B), seeds (C).

concentrations of $\mathrm{PEG}_{6000}$ in deionised $\mathrm{H}_{2} \mathrm{O}$ according to the required water potential to be induced, as described by Michel and Kaufmann (1973). Seeds were laid on double-layer filter paper sheet containing within $90 \mathrm{~mm}$ Petri dishes and supplied with $7 \mathrm{ml}$ of the test solutions. For each treatment, 100 seeds were split evenly into four replicates ( 25 seeds each). As a precaution to minimise evaporation, the dishes were wrapped hermetically with parafilm. The dishes were randomised in the dark at a constant optimum temperature of $20 \pm 1{ }^{\circ} \mathrm{C}$ in a thermostatically controlled germinator (Catav et al., 2012).

\section{Data calculation}

The final germination percentage (GP), as noted by radicle appearance, was counted every $48 \mathrm{~h}$ until no germination was observed for four following days. The experiment lasted 22 days. Seeds with significant signs of rottenness were removed.

Using the modified Timson velocity index, the germination rate index (GRI) was expressed by the formula: GRI $=\Sigma G / t$, where $G$ is the final germination (\%) and $t$ is the germination period (days) (Khan, Zia, 2007). The higher the value, the faster the germination.

In order to compare seed tolerance against various tested soluble salts, germination tolerance index (GTI \%) was used. GTI was estimated according to the formula given by Ali et al. (2017): 
Table 1. Salt concentration (C, mM), salt content (S, g $100 \mathrm{~g}^{-1}$ or $\%$ ), electrical conductivity $\left(\mathrm{EC}, \mathrm{mS} \mathrm{cm}^{-1}\right)$, and $\mathrm{pH}$ of different soluble salt agents.

\begin{tabular}{|l|c|c|c|c|}
\hline Salt agent & C & S & EC & pH \\
\hline Control & 0 & 0 & 0.01 & 7.2 \\
\hline $\mathrm{NaCl}$ & 25 & 0.15 & 3.03 & 7.9 \\
& 50 & 0.29 & 6.09 & 8.13 \\
& 75 & 0.44 & 7.69 & 7.80 \\
& 100 & 0.58 & 13.01 & 7.70 \\
\hline $\mathrm{CaCl}_{2}$ & 25 & 0.28 & 6.96 & 7.63 \\
& 50 & 0.56 & 10.71 & 7.61 \\
& 75 & 0.83 & 15.73 & 7.58 \\
& 100 & 1.11 & 18.17 & 7.51 \\
\hline $\mathrm{MgCl}_{2}$ & 25 & 0.24 & 2.67 & 7.88 \\
& 50 & 0.48 & 5.18 & 7.68 \\
& 75 & 0.71 & 6.32 & 7.72 \\
& 100 & 0.95 & 8.52 & 7.86 \\
\hline $\mathrm{Na}_{2} \mathrm{SO}_{4}$ & 25 & 0.36 & 5.04 & 8.37 \\
& 50 & 0.71 & 9.20 & 8.65 \\
& 75 & 1.06 & 12.55 & 8.39 \\
& 100 & 1.42 & 18.23 & 8.48 \\
\hline
\end{tabular}

Table 2. Results of two-way analysis of variance (F values; $p<0.05$ ) testing the effects of salts (S), concentrations (C), and their interaction $(\mathrm{S} \times \mathrm{C})$ on seed germination characteristics and seedlings responses of Lavandula stoechas.

\begin{tabular}{|l|c|c|c|}
\hline $\begin{array}{l}\text { Independent } \\
\text { variables }\end{array}$ & Salts (S) & Concentrations (c) & $\mathbf{S} \times \mathbf{C}$ \\
\hline GP (\%) & 25.79 & 222.69 & 7.89 \\
\hline GRI (\% day -1) $^{-16.10}$ & 145.90 & 4.21 \\
\hline GTI (\%) & 42.20 & 362.31 & 12.92 \\
\hline RG(\%) & 9.70 & $1.34^{\mathrm{ns}}$ & $2.17^{\mathrm{ns}}$ \\
\hline SL $(\mathrm{cm})$ & 55.05 & 289.81 & 9.71 \\
\hline RL $(\mathrm{cm})$ & 64.77 & 80.01 & 8.94 \\
\hline FW $(\mathrm{mg})$ & 31.43 & 140.07 & 6.49 \\
\hline DW $(\mathrm{mg})$ & 27.12 & 13.21 & 8.49 \\
\hline
\end{tabular}

Notes: GP - germination percentage; RGI - germination rate index; GTI - \%, germination tolerance index; RG - germination recovery; SL - shoot length; RL -radicle length; FW,- fresh weight; DW - dry weight; ${ }^{\text {ns }}$ - not significant difference.

Table 3. Germination tolerance index (\%) of Lavandula stoechas seeds treated with different soluble salts. Different letters indicate a significant difference between means ( $p<0.05)$.

\begin{tabular}{|l|c|c|c|c|}
\hline Salt levels $(\mathbf{m M})$ & $\mathbf{N a C l}$ & $\mathbf{C a C l}_{2}$ & $\mathbf{M g C l}_{2}$ & $\mathbf{N a}_{2} \mathbf{S O}_{4}$ \\
\hline 0 & $100 \mathrm{a}$ & $100 \mathrm{a}$ & $100 \mathrm{a}$ & $100 \mathrm{a}$ \\
\hline 25 & $75.2 \mathrm{~b}$ & $66.5 \mathrm{~b}$ & $64 \mathrm{~b}$ & $74.6 \mathrm{~b}$ \\
\hline 50 & $67.7 \mathrm{~b}$ & $49.8 \mathrm{c}$ & $59.6 \mathrm{~b}$ & $25.4 \mathrm{c}$ \\
\hline 75 & $37.8 \mathrm{c}$ & $41.6 \mathrm{c}$ & $54.2 \mathrm{~b}$ & $6.2 \mathrm{~d}$ \\
\hline 100 & $19.2 \mathrm{c}$ & $29.6 \mathrm{c}$ & $32.6 \mathrm{c}$ & $0 \mathrm{~d}$ \\
\hline Mean & $\mathbf{5 0 . 0}$ & $\mathbf{4 6 . 9}$ & $\mathbf{5 2 . 5}$ & $\mathbf{2 6 . 5}$ \\
\hline F value & 37.81 & 97.89 & 89.10 & 1087.3 \\
\hline
\end{tabular}

GTI $(\%)=($ GP in salt stress $/ \mathrm{GP}$ in control $) \times 100$. The lower the value, the less the tolerance.

Any seeds that failed to germinate in the different soluble salt treatments or $\mathrm{PEG}_{6000}$ solutions were transferred to distilled water to test their ability to recover germination. This recovery experiment was conducted at the same optimum conditions mentioned above. The recovery GP (RG) was calculated using the following formula (Zhang et al., 2015): $R G=a /(c-b) \times 100$, where ' $a$ ' is the seed portion that germinated after being transferred to distilled water, ' $b$ ' is the total number of seeds that already germinated in a given stress condition and ' $c$ ' is the total number of seeds.

Growth parameters were also evaluated at the end of the germination incubation period (22 days) on seedlings submitted to 0 to $0.75 \mathrm{mM}$ salt concentration and 0 to $-0.5 \mathrm{MPa}$ water potentials of $\mathrm{PEG}_{6000}$. For this purpose, five seedlings were sampled randomly from each Petri dish to measure shoot and radicle length. Fresh and dry weights were determined by using a highprecision analytical balance $(0.1 \mathrm{mg})$. Dry weight was measured after placing the seedlings at $60^{\circ} \mathrm{C}$ for $48 \mathrm{~h}$.

\section{Statistical analysis}

To ensure homogeneity of variance between means, data were tabulated and transformed (arcsine) before statistical analysis. Tukey's test was applied to perform comparison between treatments $(p<0.05)$. A two-way analysis of variance (ANOVA) was carried out to test the effects of soluble salts, concentration and their interaction on the germination patterns (GP, GRI, GTI and recovery) and growth parameters (shoot and radicle length, fresh and dry weights). On the other hand, Pearson correlation between early seed/seedling metrics and salt parameters was calculated, too. A one-way ANOVA was applied to examine the effect of PEG ${ }_{6000}$ on both germination features and seedling emergence parameters. Statistical analyses were performed by using the IBM SPSS statistics software package version 22.0.

\section{Results}

\section{Effects of soluble salts on germination parameters}

Two-way ANOVA (Table 2) indicated significant differences ( $p<$ $0.05)$ among salt agent, concentrations and their interactions, except the concentrations and salt type $\times$ concentration upon RG ( $p=0.483$ and 0.174 , respectively)

The maximum germination of $89.2 \%$ was observed in the absence of salt (control). Beyond this and regardless of the kind of salt, germination dropped steadily on increasing the stress and reached the minima at $100 \mathrm{mM}$, at which germination was severely depressed and seeds failed entirely to germinate in $\mathrm{Na}_{2} \mathrm{SO}_{4}$. At the mildest iso-concentration $(25 \mathrm{mM})$, however, seeds stressed by $\mathrm{Na}_{2} \mathrm{SO}_{4}$ exhibited higher GP (Fig. 2).

In the seeds that did not receive any treatments, the germination rate, assessed using Timson index, showed the highest amount $\left(7.4 \%\right.$ day $\left.^{-1}\right)$, whereas salinity stress increase decreased GRI, except in seeds treated with $\mathrm{MgCl}_{2}$, the higher value of GRI was recorded at $75 \mathrm{mM}\left(4.5 \%\right.$ day $\left.^{-1}\right)$. On the other hand, even though at the iso-concentration of $25 \mathrm{mM}$, the highest GRI 

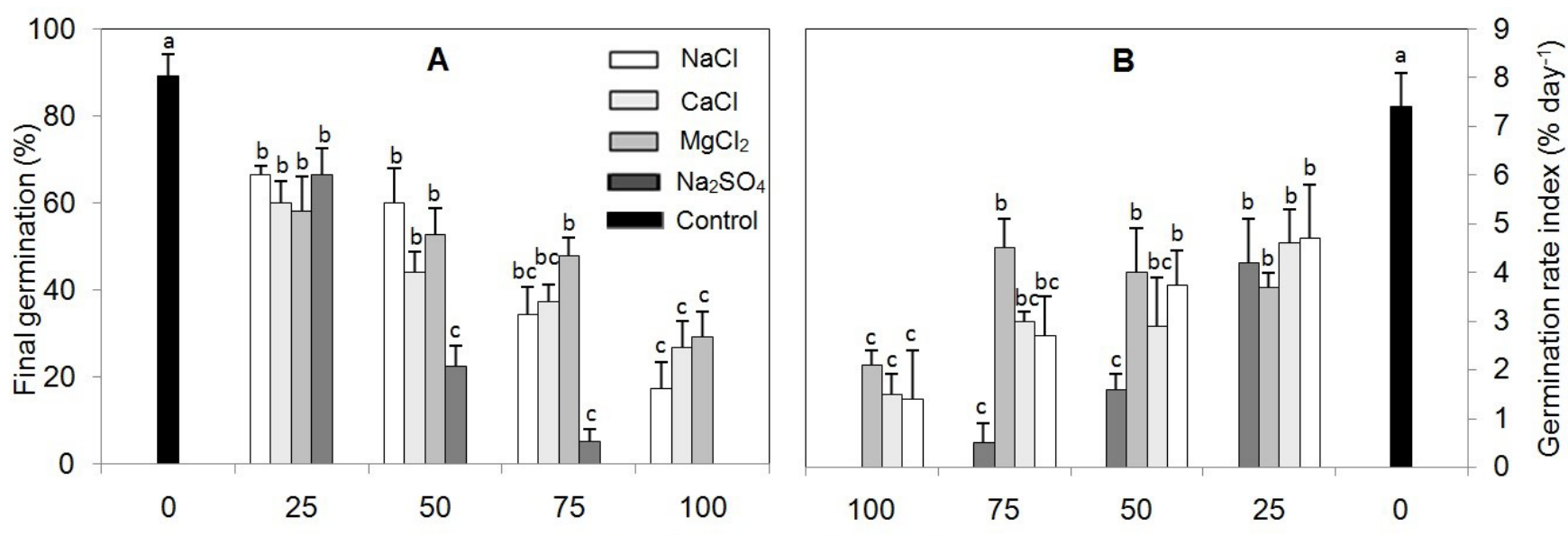

Solution concentration $(\mathrm{mM})$

Fig. 2. Final germination percentage (A) and germination rate index (B) of Lavandula stoechas seeds at different concentrations of soluble salts. Bars represent mean \pm S.E $(n=4)$. Different letters indicate a significant difference between means $(p<0.05)$.

value was noticed in the seeds treated with $\mathrm{NaCl}$, no significant differences were recorded among the four salts; while at 50 and $75 \mathrm{mM}$, seeds of L. stoechas showed a significant decrease in GRI when stressed by $\mathrm{Na}_{2} \mathrm{SO}_{4}$ (Fig. 2). Overall, the inhibitory effect of salts on GRI was most pronounced at $100 \mathrm{mM}$.

A little portion of seeds among those that failed to germinate in different $\mathrm{MgCl}_{2}$ concentrations were capable of recovering germination when transferred to distilled water $(>31.5 \%)$ as compared to other salts. However, the concentration of $25 \mathrm{mM}$ $\mathrm{NaCl}$ had affected less the seeds' ability to recover (despite statistically insignificant effects being recorded among $\mathrm{NaCl}$ concentrations) (Fig. 3). Surprisingly, the RGs of seeds stressed by 75 and $100 \mathrm{mM} \mathrm{CaCl}_{2}$ were higher than those of 25 and $50 \mathrm{mM}$ $\mathrm{CaCl}_{2}$ (60 and $58.7 \%$ vs. 49.2 and $30.6 \%$, respectively).

The GTI of $L$. stoechas seeds declined with increasing salinity, and the lowest GTI was recorded at $100 \mathrm{mM} \mathrm{Na}_{2} \mathrm{SO}_{4}$. Moreover, at this same concentration, GTI was decreased more by $\mathrm{NaCl}$, $\mathrm{CaCl}_{2}$ and, $\mathrm{MgCl}_{2}$ (19.2, 29.6 and $32.6 \%$, respectively) compared to other concentrations. At moderate salt concentrations (25 and $50 \mathrm{mM}$ ), L. stoechas seeds tolerated better $\mathrm{NaCl}$, whereas at 75 and $100 \mathrm{mM}$, the seeds' salt tolerance was higher in $\mathrm{MgCl}_{2}$. Overall, the GTI revealed that $L$. stoechas has a better tolerance with $\mathrm{MgCl}_{2}$ than with $\mathrm{NaCl}, \mathrm{CaCl}_{2}$ and $\mathrm{Na}_{2} \mathrm{SO}_{4}$ (Table 3).

\section{Effect of soluble salts on early plant growth}

All salts tested adversely influenced shoot and radicle length. Seedlings sprouting in control reached the maximum shoot length (up to $3.9 \mathrm{~cm}$ tall). Regarding root length, a higher value was recorded at $25 \mathrm{mM} \mathrm{MgCl}_{2}$ (1.8 cm long), while $\mathrm{Na}_{2} \mathrm{SO}_{4}$ had more inhibitory effects on shoot and radicle length than other salts. Even $50 \mathrm{mM} \mathrm{Na} \mathrm{SO}_{4}$ decreased steeply shoot and radicle length by $94.9 \%$ and $87.5 \%$, respectively, compared to distilled water (Fig. 4). In spite of the decrease in length, neither of these two parameters, indeed, was significantly affected by $\mathrm{CaCl}_{2}$ (no statistically significant differences were obtained among means).

Salinity had a significant impact on seedlings' fresh weight, and the non-stressed seedlings, in fact, attained a maximum average of up to $7.25 \mathrm{mg}$. The fresh weight decreased by increasing

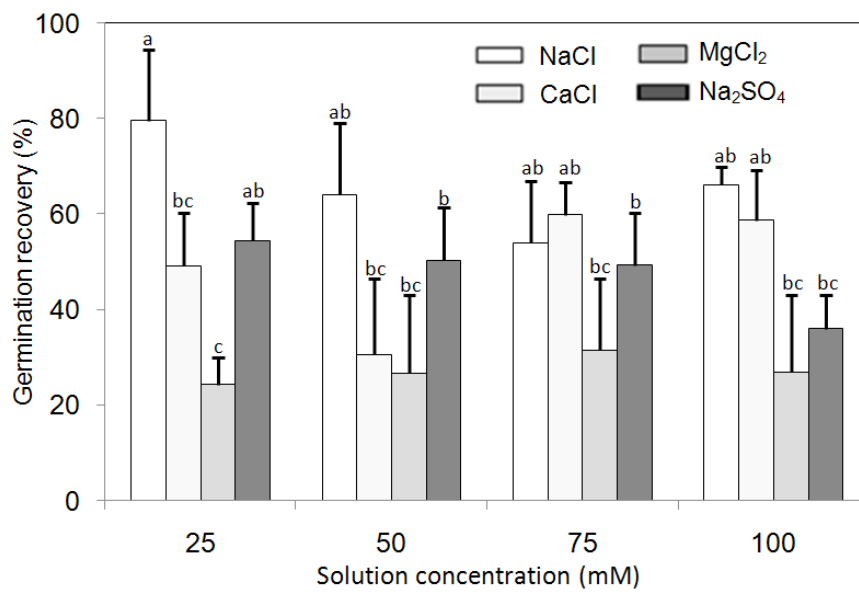

Fig. 3. Recovery germination percentage of Lavandula stoechas seeds stressed with different soluble salts. Bars represent mean \pm S.E (n $=4)$. Different letters indicate a significant difference between means $(p<0.05)$.

salinity (Fig. 5), albeit no significant differences $(p<0.05)$ were obtained among $\mathrm{NaCl}, \mathrm{CaCl}_{2}$ and $\mathrm{MgCl}_{2}$ at all tested concentrations. The increase in dry weight, however, was promoted by these three salts at all concentrations, many of which exceeded that of control $(0.28 \mathrm{mg})$; it ranged from $0.38 \mathrm{mg}\left(25 \mathrm{mM} \mathrm{MgCl}_{2}\right)$ to $0.30 \mathrm{mg}\left(75 \mathrm{mM} \mathrm{CaCl}_{2}\right)$, except at $75 \mathrm{mM} \mathrm{MgCl}_{2}(0.26 \mathrm{mg})$ (Fig. 5). $\mathrm{Na}_{2} \mathrm{SO}_{4}$ declined dramatically fresh and dry weights at both concentrations ( 25 and $50 \mathrm{mM}$ ).

\section{Correlation among seed/seedling metrics and salts}

Germination metrics (i.e. GP, GRI, GTI and RG) and almost all early seedling response parameters (i.e. shoot length, radicle length and fresh weight) were best correlated mainly with EC, salt content and concentration of all tested soluble salts. Notably, the correlation coefficients were equal in $\mathrm{NaCl}$ treatment among 


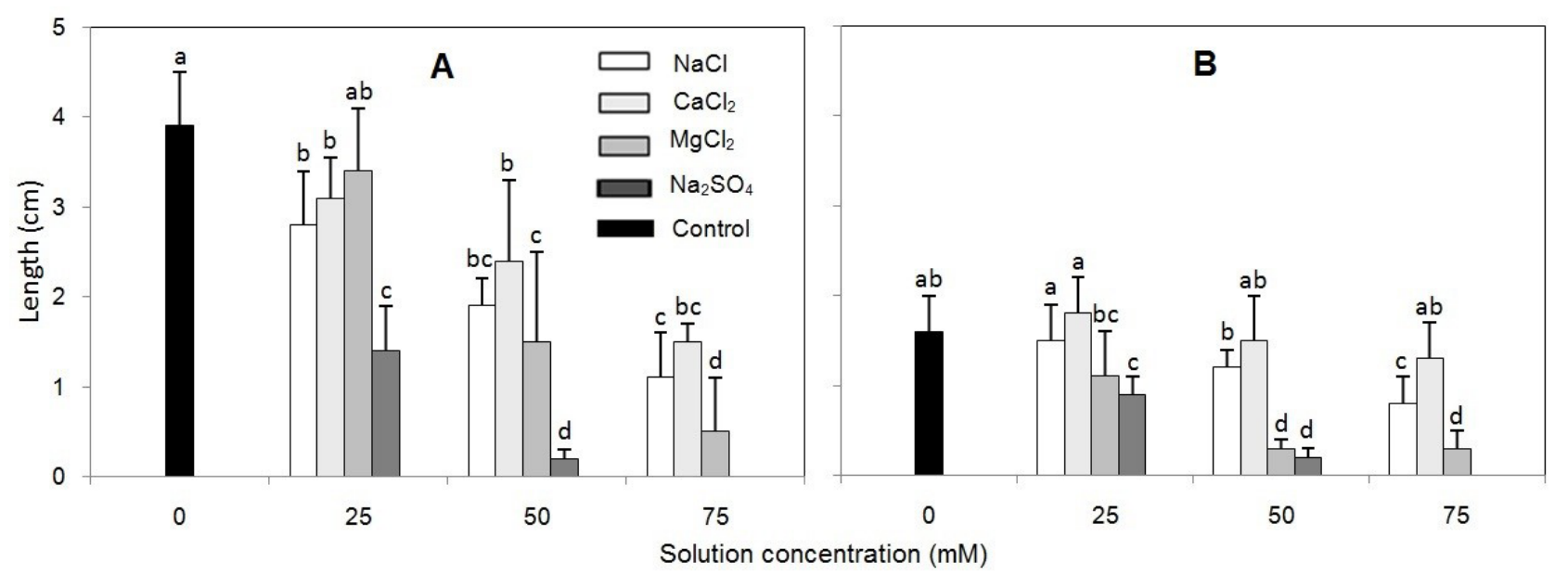

Fig. 4. Shoot (A) and radicle length (B) of Lavandula stoechas seedlings (22 days) at different concentrations of salt agents. Bars represent mean \pm S.E $(\mathrm{n}=20)$. Different letters indicate a significant difference between means $(p<0.05)$.

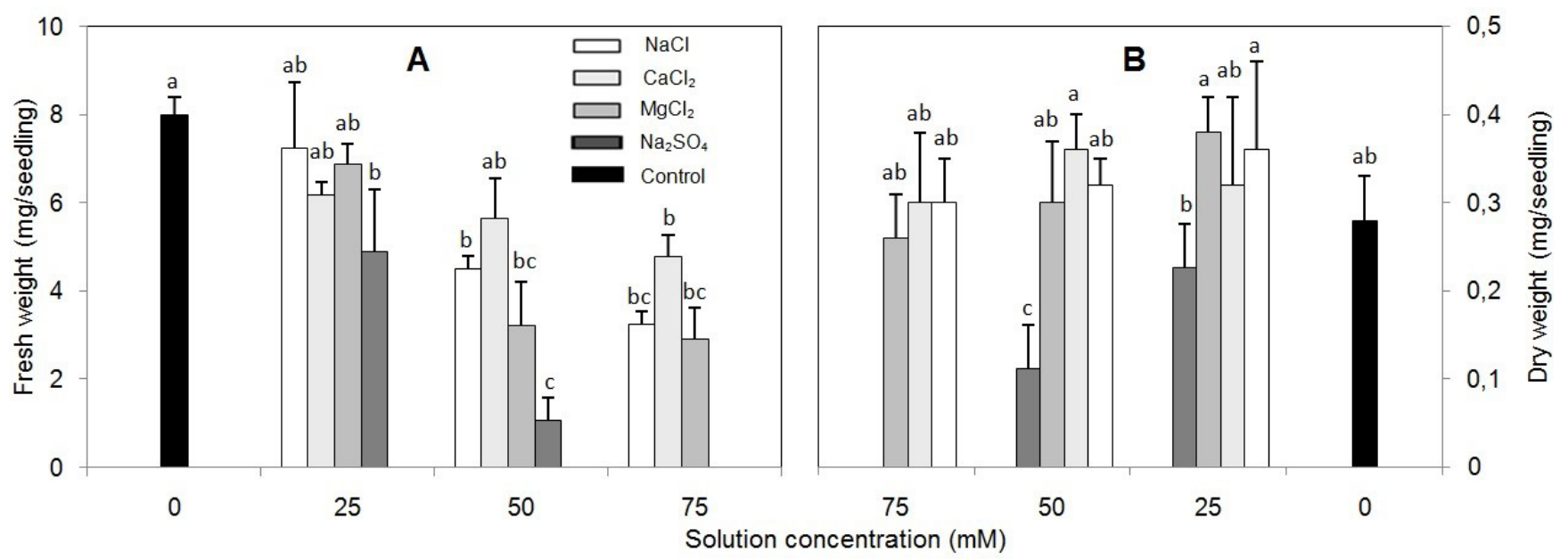

Fig. 5. Fresh (A) and dry weight (B) of Lavandula stoechas seedlings grown under different soluble salt agents. Bars represent mean \pm S.E (n $=20)$. Different letters indicate a significant difference between means $(p<0.05)$.

C, S, EC and shoot length ( $r=-0.957)$ and among S, C and fresh weight $(r=-0.928)$. Dry weight, meanwhile, was best correlated with $\mathrm{pH}$ in $\mathrm{NaCl}, \mathrm{CaCl}_{2}$ and $\mathrm{MgCl}_{2}$. The $\mathrm{pH}$ was strongly correlated $(r=-0.900 ; p<0.01)$ as well with GR in $\mathrm{MgCl}_{2}$ (Table 4).

\section{Response to water stress induced by using PEG6000}

Water stress application depressed germination of $L$. stoechas seeds (Table 5). Control showed the maximum GP, whereas the GP decreased significantly when water stress increased from $-0.25 \mathrm{MPa}$ upwards, with total inhibition in seed germinability observed at $-1 \mathrm{MPa}$. As the water potential fell, GRI dropped too (0 MPa, $7.4 \%$ day $^{-1}$ vs. $-0.75 \mathrm{MPa}, 0.8 \%$ day $\left.^{-1}\right)$. Despite the negative effect of moisture stress upon RG, insignificant statistical difference was noticed among the levels. The water stress prevented shoot growth, water imbibition as well as dry mass production, as reflected by their lower values as the water po- tential decreases (from 0 to $-0.5 \mathrm{MPa}$ ). Interestingly, low water potential had almost no effect on $L$. stoechas radicle length, as the values ranged between 1.5 and $1.6 \mathrm{~cm}$ (see Table 5).

\section{Discussion}

Few studies have been conducted to examine the effects of diverse soluble salts and water stress on seed emergence and seedling growth in medicinal plants. In this study, we evaluated salt and drought tolerance of $L$. stoechas under the presence of four soluble salts and different levels of $\mathrm{PEG}_{6000}$ and their effects on seed germination and early seedling growth.

Seeds of $L$. stoechas displayed a wide viability range, $89.2 \%$ germination at non-stress condition, with a characteristic nondeep dormancy; however, as supposed, salinity induced resulted in a corresponding decrease in seed germination. Such results in germination reduction have been reported by using either $\mathrm{NaCl}$ 
only, as in Retama raetam (Mehdadi et al., 2017) and P. pallida (Aljasmi et al., 2021), or various single soluble salts, as in Artemisia herba-alba (Nedjimi, Zemmiri, 2019) and Marrubium vulgare (Nedjimi et al., 2020).

In our study, $\mathrm{Na}_{2} \mathrm{SO}_{4}$ was more aggressive than other soluble salts on Lavandula stoechas seed germination and seedling growth. The results of previous studies on the effects of different salts in germination are contradictory and species specific. For example, $\mathrm{NaCl}$ was more inhibitory than $\mathrm{Na}_{2} \mathrm{SO}_{4}$ on the germination of the glycophyte Pinus halepensis (Nedjimi, 2017) and the halophytes Juncus acutus and Arthrocnemum macrostachyum (Vicente et al., 2009), but the toxicity of $\mathrm{Na}_{2} \mathrm{SO}_{4}$ was more pronounced than $\mathrm{NaCl}$ on the germination of Prosopis strombulifera (Sosa et al., 2005), Ceratoides latens (Zhang et al., 2015), Medicago sativa, Elymus dahuricus (Zhang et al., 2018) and M. vulgare (Nedjimi et al., 2020). Glycophytes are usually less tolerant to salt stress than halophytes and both use different mechanisms in tackling salt ions (Qudir et al., 2008). However, the contradictory germination response is not necessarily linked to whether a species is salt tolerant or salt sensitive (Zhang et al., 2018).

The salt tolerance of Lavandula stoechas seeds is ordered as follows: $\mathrm{MgCl}_{2}>\mathrm{NaCl}>\mathrm{CaCl}_{2}>\mathrm{Na}_{2} \mathrm{SO}_{4}$. This indicates that evaluating multiple kinds of salts, rather than just $\mathrm{NaCl}$, should be considered when testing a plant's salt tolerance. Panuccio et al. (2014) reported that Chenopodium quinoa seed germination tolerance was in the order: $\mathrm{MgCl}_{2}>\mathrm{CaCl} 2>\mathrm{NaCl}$. Nedjimi and Zemmiri (2019) reported the order of toxicity on seed germination of Artemisia herba-alba as $\mathrm{MgCl}_{2}>\mathrm{Na}_{2} \mathrm{SO} 4>\mathrm{NaCl}>$ $\mathrm{CaCl}_{2}$. The latter trend was the same in the halophyte Suaeda salsa (Duan et al., 2007) and the xerophyte Zygophyllum simplex (Al-Khateeb et al., 2010). Interestingly, seeds of Phragmites karka demonstrated enhanced tolerance to and germinated significantly more with $\mathrm{MgCl}_{2}$ at a low temperature; at moderate and high temperatures, however, it became more sensitive to $\mathrm{MgCl}_{2}$ than other salts that were applied (Zehra et al., 2013).

There is a perception that the variation in response of seeds to different soluble salts is due to the difference in osmotic stress caused by these salts at the same concentrations, albeit specific ion injury effects cannot be discarded. Moreover, salts may act specifically in saline soils, with effects ranging from beneficial to noxious for germination depending on doses (Tobe et al., 2004). The relatively high germination in Lavandula stoechas at lower salt concentration indicates that seeds might benefit from salts. Several studies demonstrated that seeds could stamp out the negative osmotic effects of the exogenous application of salts
Table 4. Pearson correlation coefficients between seed germination/ early seedling metrics and salt parameters.

\begin{tabular}{|c|c|c|c|c|c|}
\hline \multicolumn{2}{|c|}{ Salt agent } & C & $S$ & EC & $\mathrm{pH}$ \\
\hline \multirow[t]{8}{*}{$\mathrm{NaCl}$} & GP & $-0.963^{\star *}$ & $-0.964^{\star \star}$ & $-0.944^{* *}$ & -0.361 \\
\hline & GR & $-0.905^{\star *}$ & $-0.926^{\star *}$ & $-0.912^{\star *}$ & $-0.552^{\star}$ \\
\hline & GTI & $-0.958^{\star *}$ & $-0.959^{\star *}$ & $-0.940^{\star *}$ & -0.352 \\
\hline & RG & -0.318 & -0.319 & -0.232 & 0.064 \\
\hline & SL & $-0.957^{\star \star}$ & $-0.957^{\star *}$ & $-0.957^{\star \star}$ & $-0.689^{* \star}$ \\
\hline & $\mathrm{RL}$ & $-0.851^{\star *}$ & $-0.810^{\star *}$ & $-0.765^{\star *}$ & -0.293 \\
\hline & FW & $-0.928^{\star *}$ & $-0.928^{\star *}$ & $-0.927^{\star *}$ & $-0.588^{*}$ \\
\hline & DW & 0.115 & 0.119 & 0.153 & 0.423 \\
\hline \multirow{8}{*}{$\mathrm{CaCl}_{2}$} & GP & $-0.936^{\star *}$ & $-0.937^{\star *}$ & $-0.961^{\star *}$ & $-0.771^{\star \star}$ \\
\hline & GR & $-0.905^{\star \star}$ & $-0.907^{\star *}$ & $-0.928^{\star \star}$ & $-0.718^{\star \star}$ \\
\hline & GTI & $-0.948^{\star \star}$ & $-0.949^{* *}$ & $-0.973^{\star \star}$ & $-0.714^{\star \star}$ \\
\hline & RG & 0.427 & 0.423 & \begin{tabular}{|l|}
0.459 \\
\end{tabular} & -0.446 \\
\hline & SL & $-0.935^{\star *}$ & $-0.945^{\star \star}$ & $-0.936^{\star *}$ & $-0.649^{* *}$ \\
\hline & $\mathrm{RL}$ & -0.385 & -0.383 & -0.340 & -0.016 \\
\hline & FW & $-0.899^{\star *}$ & $-0.900^{* *}$ & $-0.922^{\star *}$ & $-0.809^{* *}$ \\
\hline & DW & 0.259 & 0.263 & 0.272 & 0.378 \\
\hline \multirow[t]{8}{*}{$\mathrm{MgCl}_{2}$} & GP & $-0.899^{\star *}$ & $-0.901^{\star *}$ & $-0.919^{\star *}$ & $-0.883^{\star *}$ \\
\hline & GR & $-0.772^{\star *}$ & $-0.774^{\star *}$ & $-0.812^{\star *}$ & $-0.900^{\star *}$ \\
\hline & GTI & $-0.924^{\star *}$ & $-0.926^{\star *}$ & $-0.946^{\star *}$ & -0.860 \\
\hline & RG & 0.113 & 0.112 & 0.103 & -0.119 \\
\hline & SL & $-0.936^{\star *}$ & $-0.936^{\star *}$ & $-0.919^{* *}$ & -0.416 \\
\hline & $\mathrm{RL}$ & $-0.901^{\star \star}$ & $-0.904^{\star *}$ & $-0.932^{\star \star}$ & $-0.576^{\star *}$ \\
\hline & FW & $-0.925^{\star \star}$ & $-0.927^{\star \star}$ & $-0.944^{\star *}$ & -0.482 \\
\hline & DW & -0.207 & -0.204 & -0.145 & 0.389 \\
\hline \multirow[t]{8}{*}{$\mathrm{Na}_{2} \mathrm{SO}_{4}$} & GP & $-0.957^{\star *}$ & $-0.956^{\star *}$ & $-0.945^{\star \star}$ & $-0.763^{\star \star}$ \\
\hline & GR & $-0.817^{\star *}$ & $-0.816^{\star *}$ & $-0.936^{\star *}$ & $-0.848^{\star \star}$ \\
\hline & GTI & $-0.963^{\star *}$ & $-0.962^{\star *}$ & $-0.951^{\star *}$ & $-0.786^{\star \star}$ \\
\hline & RG & $-0.603^{\star}$ & $-0.605^{\star}$ & $-0.628^{\star}$ & -0.098 \\
\hline & SL & $-0.919^{\star *}$ & $-0.922^{\star *}$ & $-0.948^{\star \star}$ & $-0.938^{\star \star}$ \\
\hline & $\mathrm{RL}$ & $-0.942^{\star *}$ & $-0.943^{\star *}$ & $-0.953^{\star \star}$ & $-0.827^{\star \star}$ \\
\hline & FW & $-0.960^{\star *}$ & $-0.961^{\star *}$ & $-0.971^{\star *}$ & $-0.834^{* \star}$ \\
\hline & DW & $-0.937^{\star *}$ & $-0.936^{\star *}$ & $-0.921^{\star *}$ & $-0.631^{\star}$ \\
\hline
\end{tabular}

Notes: GP - germination percentage; GRI - germination rate index; GTI - germination tolerance index; RG - germination recovery; SL shoot length; RL - radicle length; FW - fresh weight; DW - dry weight. In bold are the highest values of correlation coefficients for each seed/seedling metric, which means the best correlated parameter: * - Correlation is significant at the 0.05 level; ${ }^{* *}$ - Correlation is significant at the 0.01 level.

Table 5. Seeds germination/early seedling parameters of Lavandula stoechas, incubated at $20^{\circ} \mathrm{C}$, in response to water stress (mean \pm SE, $\mathrm{n}=$ $4)$ as induced by $\mathrm{PEG}_{6000}$. Different letters indicate a significant difference between means $(p<0.05)$.

\begin{tabular}{|c|c|c|c|c|c|c|c|}
\hline Water potantial (MPa) & GP (\%) & GRI $\left(\%\right.$ day $\left.^{-1}\right)$ & RG (\%) & SL $(\mathrm{cm})$ & $\mathrm{RL}(\mathrm{cm})$ & FW (mg/seedling) & DW (mg/seedling) \\
\hline 0 & $89.2 \pm 5^{\mathrm{a}}$ & $7.4 \pm 0.7^{\mathrm{a}}$ & 1 & $4.1 \pm 0.4^{\mathrm{a}}$ & $1.5 \pm 0.2^{\mathrm{a}}$ & $8.2 \pm 1.2^{\mathrm{a}}$ & $0.28 \pm 0.06^{\mathrm{a}}$ \\
\hline-0.25 & $41.2 \pm 2.2^{\mathrm{b}}$ & $3.6 \pm 0.4^{\mathrm{b}}$ & $63.4 \pm 8^{\mathrm{a}}$ & $3.2 \pm 0.2^{\mathrm{b}}$ & $1.6 \pm 0.4^{\mathrm{a}}$ & $3.5 \pm 0.5^{\mathrm{b}}$ & $0.20 \pm 0.05^{\mathrm{ab}}$ \\
\hline-0.5 & $26.6 \pm 6^{c}$ & $2.0 \pm 0.8^{\mathrm{c}}$ & $49.2 \pm 4^{\mathrm{a}}$ & $1.8 \pm 0.4^{\mathrm{c}}$ & $1.5 \pm 0.5^{\mathrm{a}}$ & $1.6 \pm 0.4^{\mathrm{c}}$ & $0.14 \pm 0.06^{\mathrm{b}}$ \\
\hline-0.75 & $8 \pm 2^{\mathrm{d}}$ & $0.8 \pm 0.2^{c}$ & $45.2 \pm 10^{\mathrm{a}}$ & 1 & 1 & 1 & 1 \\
\hline-1.0 & $0.0^{\mathrm{d}}$ & 1 & $42.2 \pm 6^{\mathrm{a}}$ & / & / & / & l \\
\hline$F$ value & 161.54 & 82.13 & 2.47 & 41.93 & 0.19 & 151.0 & 5.40 \\
\hline
\end{tabular}

Notes: GP - germination percentage; GRI - germination rate index; RG - germination recovery; SL - shoot length; RL - radicle length; FW - fresh weight; DW - dry weight. 
through accumulation of ions to maintain lower water potential, and thus increase water absorption (Yagmur, Kaydan, 2008; Li et al., 2011). This trait is considered as a passive metabolic process that does not require energy/respiration. Under salinity, the slowdown in germination speed, expressed here by GRI, could be owing to the duration necessary for seeds to trigger mechanisms allowing them to adjust their osmotic pressure (Medjebeur et al., 2018).

All plant species might deploy either salt-tolerance or saltavoidance strategies to withstand soil salinity increment. Salt tolerance characteristics are reflected by maintenance of highest GPs and germination rates under high salinities, while a high RG after the alleviation of salinity reflects a salt-avoidance strategy (Zhang et al., 2015). Unlike the final GP, a poor RG was exhibited when seeds were stressed with $\mathrm{MgCl}_{2}$ regadless of the applied concentration, and transferred to distilled water $(<30 \%)$. Similar results were reported in Phragmites karka, in which seeds failed to recover germination in $\mathrm{MgCl}_{2}$ when incubated at the temperature regime of $25 / 35^{\circ} \mathrm{C}$ and transferred to proper condition (Zehra et al., 2013). In the remaining soluble salts, Lavandula stoechas seeds showed a relatively high RG. Our results are in close agreement with those of Zhang et al. (2015) who reported that Suaeda microphylla, Chenopodium rubrum and Kalidium foliatum resumed high recovery germination after the seeds were transferred from $\mathrm{NaCl}$ and $\mathrm{Na}_{2} \mathrm{SO}_{4}$ to deionised water. The recovery response seems to indicate that the germination inhibition of Lavandula stoechas in different salts is probably due to both osmotic stress and specific ion toxicity. In this case, Zehra et al. (2013) suggested that the osmotic and specific ion effects may combine and make it difficult to distinguish the proportional contribution of two stresses. Ungar (1996) stated that, in salty habitat, instead of commencing germination promptly after being released from the maternal plant, dormancy of seeds for an extended period may be a selective advantage, since it enables seeds to emerge and establish a plant as soon as excessive concentrations of salts are leached by rains.

Concomitant to osmotic adjustment governed by salt ion absorption, salt-adaptive plants are also capable to synthesise compatible organic solutes, such as proline, glycine betaine, free sugar and polyalcohol, in the cytoplasm to prevent water loss (Yang et al., 2007); thus, this trait is an active metabolic process. Despite being a glycophyte, L. stoechas has a tendency to uptake water, as reflected by maintaining high shoot and root growth performance as well as high fresh weight value at moderate salt concentration $(25 \mathrm{mM})$, whereas these parameters dropped as salinity increased. This suggests that, at milder salt solution, the mechanisms preventing ions from acting as toxic substances are active, mainly the osmotic adjustment process, and the accumulated osmolytes are involved in protection against free radicals (De Souza et al., 2016). Further, salt-sensitive plants, such Medicago sativa and Elymus dahuricus, had shown a dramatic decrease in the radicle length, but not in shoot length, when they were subjected to low $\mathrm{NaCl}$ and $\mathrm{Na}_{2} \mathrm{SO}_{4}$ levels (Zhang et al., 2018). However, Physalis angulata, an ethnomedicinal glycophyte, kept a high seedling fresh weight at 8 $\mathrm{mS} \mathrm{cm}{ }^{-1} \mathrm{NaCl}$ (>75 mM) (De Souza et al., 2016). Different soluble salts, except $\mathrm{Na}_{2} \mathrm{SO}_{4}$, had a positive effect on dry weight compared to the control. This could be attributed to the beneficial roles of $\mathrm{Mg}^{2+}$ and $\mathrm{Ca}^{2+}$. The former is involved in translocation of assimilates and enhanced nutrient utilisation (Senbayram et al., 2015). The latter helps in preserving the membrane stability, reduction of membrane leakage, forming cell walls and regulation of ion selectivity (White, Broadley, 2003).

Numerous studies have simulated salinity by using different concentration levels (C, mM) (Sosa et al., 2005; Zehra et al., 2013). This approach may be used because halophyte is defined as a plant that has the ability to complete its life cycle under salinity levels of $\geq 200 \mathrm{mM} \mathrm{NaCl}$ (Flowers, Colmer, 2008). Salt content (S, g $\left.100 \mathrm{~g}^{-1}\right)$ and EC ( $\left.\mathrm{mS} \mathrm{dm}^{-1}\right)$, however, have been used relatively less frequently than salt concentration to assess the effects of salts on germination and seedling growth (Ungar, 1996; Bina, Bostani, 2017). These two salt parameters were preferred by some researchers for use in studying glycophyte germination behaviour or crop yield under controlled conditions or in field (Qudir et al., 2008; Kanawapee et al., 2012, De Souza et al., 2016). The three salt parameters (i.e. C, S and EC) are strongly correlated with almost all germination/early seedling metrics. These parameters are considered appropriate for the evaluation of salinity tolerance in Lavandula stoechas seed germination and early seedling growth. It is also clear that $\mathrm{pH}$ was weakly significantly correlated to germination and seedling growth, even though many researchers have emphasised the effect of $\mathrm{pH}$ on the growth of plants exposed to salts (Basto et al., 2013; Huang et al., 2017). Ali et al. (2017) studied the effect of buffer solutions on seed germination of Salsola foetida, a North African halophyte. They concluded that $\mathrm{pH}$ is not a limiting factor on the final seed GP and germination rate of this species. In addition, $\mathrm{pH}$ was not a limiting factor on germination either in Sorghum bicolor (Zhao et al., 2014) or in Leymus chinensis (Ma et al., 2015). Zhang et al. (2018) hypothesised that, even in sodic conditions, the $\mathrm{pH}$ is not a relevant indicator for the negative effects in salty soils on the early phases of plant establishment. The strong correlation between $\mathrm{pH}$ and the germination rate in $\mathrm{MgCl}_{2}(r=-0.900, p$ $<0.01)$ appears to be unique and deserves further investigation.

Higher tolerance to lower water potential during seed germination has been considered as an adaptive strategy for plants inhabiting unpredictable ecosystems (Fyfield, Gregory, 1989; Zeng et al., 2010). Both seed germination and the germination rate of Lavandula stoechas decreased significantly with increasing water stress, and germination stopped completely at $-1 \mathrm{MPa}$. This figure is considered as the germination threshold tolerance value of this species. Consistent results have already been obtained in many studies on other Lamiaceae species, as Abbad et al. (2011) and Dadach and Mehdadi (2018) reported that the seeds of Thymus broussonetii, T. maroccanus and Ballota hirsuta were harshly affected by the drop in water potential and, per contra, they exhibited high seed germinability in the absence of stress. Similarly, Sideritis incana and Stachys ocymastrum, two medicinal plants, showed lower GP and GRI at $-0.5 \mathrm{MPa}$, and germination was absolutely inhibited at $-1 \mathrm{MPa}$ (Dadach, Mehdadi, 2021). Other plants flourishing in the Mediterranean climate, such as Stipa tenacissima and Thymus fontanesii, showed higher tolerance threshold reaching up to $-1.6 \mathrm{MPa}$ (Krichen et al., 2014; Dadach, Mehdadi, 2021). Ali et al. (2017) anticipated that, in the drought-sensitive seeds, process of water percolation remains incomplete. The decrease in water potential increases the osmotic potential, creating deficiency in seed hydration and causing changes in enzymatic activities, a general reduction in hydrolysis and utilisation of major natural food reserves of seeds, notably carbohydrates, lipids and proteins, which subsequently prevent seed germination (Steiner, Zufo, 2019). 
Seedling growth was also affected by the rise in water stress, whereas the root length was relatively constant at all PEG-tested solutions, indicating that Lavandula stoechas entertains root growth as a coping strategy to overcome drought, and this can ensure that root system, during the earliest phases after germination, reaches deeper groundwater. In fact, Faisal et al. (2019) emphasised that the effects of drought depend not only upon the degree and length of water scarcity, but also upon the plant growth phase. Seeds that failed to germinate under water stress and had germinated after being transferred to distilled water are the portion of seeds that form transient soil seed banks germinating naturally in the period of years receiving sufficient amount of rainfall. We assume rainfalls are the predominant environmental cue in triggering seed germination of butterfly lavender. Adequate precipitation adjusts temperatures, mitigates soil salinity and raises water potential (Khan, Gulzar, 2003).

\section{Conclusion}

The present study was conducted to evaluate the impact of different soluble salts and water stress on germination and early growth of L. stoechas, a potential species for rehabilitation of degraded coastal lands. Our results demonstrate that despite the negative effect of salinity on germination and seedling growth, $L$. stoechas seeds were capable to emerge at moderate salt concentrations $(<75 \mathrm{mM})$ in all applied salt agents. Susceptibility to salt stress indicates that this species is able to thrive in a wide range of habitats where particular ion composition may act favourably for its subsistence. L. stoechas is a promising plant for use in the restoration of the Mediterranean coastal lands, which are under serious threat of soil salinisation. Regarding the confirmed dreadful effects of water stress on germinability and seedling response, we recommend introducing this species in habitats with sufficient annual precipitation amounts to mitigating the impacts of prolonged drought spell and improving seedling fitness. Still, results of germination experiments with a single salt would not always be applicable to field conditions. Complementary studies on germination and seedling growth of this species must focus more on the effects of different combinations of salts (two mixed or more) on seeds/seedlings responses.

\section{Acknowledgements}

We thank Mrs Boudersa Samira for help with the experiments and in data collection. We sincerely thank both the editor and the anonymous reviewers, whose insightful comments and suggestions improved the quality of the manuscript. This study was supported by the General Direction of Scientific Research and Technological Development (D.G.R.S.D.T., the Ministry of Higher Education and Scientific Research, Algeria).

\section{References}

Abbad, A., Belaqziz, R., Bekkouche, K. \& Markou M. (2011). Influence of temperature and water potential on laboratory germination of two Moroccan endemic thymes: Thymus maroccanus Ball. and Thymus broussonetii Boiss. African Journal of Agricultural Research, 6, 4740-4745. DOI: $10.5897 / A J A R 10.574$.

Alexakis, D., Gotsis, D. \& Giakoumakis S. (2015). Evaluation of soil salinization in a Mediterranean site (Agoulinitsa district-West Greece). Arabian Journal of Geosciences, 8, 1373-1383. DOI: 10.1007/s12517-0141279-0.
Alfarrah, N. \& Walraevens K. (2018). Groundwater Overexploitation and Seawater Intrusion in Coastal Areas of Arid and Semi-Arid Regions. Water, 10(2), 143. DOI: 10.3390/w10020143.

Ali. H.H., Naeem, M., Ali, H.H., Tanveer, A., Javaid, M.M., Peerzada, A.M. \& Chauhan B.S. (2017). Effect of environmental factors on germination of Salsola foetida: potential species for rehabilitation of degraded rangelands. Rangeland Ecology \& Management, 70(5), 638-643. DOI: 10.1016/j.rama.2017.02.003.

Aljasmi, M., El-Keblawy, A. \& Mosa K.A. (2021) Abiotic factors controlling germination of the multipurpose invasive Prosopis pallida: towards aforestation of salt-afected lands in the subtropical arid Arabian desert. Trop. Ecol., 62, 116-125. DOI: 10.1007/s42965-020-00124-3.

Al-Khateeb, W.M., Muhaidat, R.M., Odat, N., Sawaie, A., Lahham, J.N. \& AlOqlah A. (2010). Interactive effects of salinity, light and temperature on seed germination of Zygophyllum simplex L. (Zygophyllaceae). International Journal of Integrative Biology, 10(1), 9-13.

Basto, S., Dorca-Fornell, C., Thompson, K. \& Rees M. (2013). Effect of pH buffer solutions on seed germination of Hypericum pulchrum, Campanula rotundifolia and Scabiosa columbaria. Seed Sci. Technol., 41(2), 298-302. DOI: 10.15258/sst.2013.41.2.12.

Belgacem, A.O., Salem, H.B., Bouaicha, A. \& El-Mourid M. (2008). Communal rangeland rest in arid area, a tool for facing animal feed costs and drought mitigation: the case of Chenini Community, Southern Tunisia. J. Biol. Sci., 8, 822-825. DOI: 10.3923/jbs.2008.822.825.

Benabdelkader, T., Zitouni, A., Guitton, Y., Jullien, F., Maitre, D., Casabianca, H., Legendre, L. \& Kameli A. (2011). Essential oils from wild populations of Algerian Lavandula stoechas L.: composition, chemical variability, and in vitro biological properties. Chemistry \& Biodiversity, 8(5), 937-953. DOI: $10.1002 / \mathrm{cbdv} .201000301$.

Bina, F. \& Bostani A. (2017). Effect of salinity $(\mathrm{NaCl})$ stress on germination and early seedling growth of three medicinal plant species. Advancements in Life Sciences, 4 (3), 77-83.

Boukhatem, M.N., Ferhat, M.A. \& Kameli A. (2020). Butterfly lavender (Lavandula stoechas $\mathrm{L}$.): an aromatic plant with several medicinal properties. Phytothérapie, 18(1), 30-44. DOI: 10.3166/phyto-2019-0163.

Catav, Ș.S., Bekar, I.., Ateş, B.S., Ergan, G., Oymak, F., Ulker, E.D. \& Tavşanoğlu C. (2012). Germination response of five eastern Mediterranean woody species to smoke solutions derived from various plants. Turk. J. Bot., 36, 480-487. DOI: $10.3906 /$ bot-1111-12.

Cherif, K., Mehdadi, Z., Elkhiati, N., Latreche, A. \& Ramdani M. (2017). Floristic composition of the mountainous massif of Tessala (Algerian West): Biodiversity and regressive dynamics of the forest ecosystem. Journal of Materials and Environmental Science, 8(9), 3184-3191. https://www.jmaterenvironsci.com/Document/vol8/vol8_N9/337-JMES-1881-Cherifi.pdf

Dadach, M. \& Mehdadi Z. (2018). Germination responses of Ballota hirsuta seeds under conditions of temperature, salinity and water stress. Hellenic Plant Protection Journal, 11, 34-39. DOI: 10.2478/hppj-2018-0004.

Dadach, M. \& Mehdadi Z. (2021). Drought tolerance of three ethnomedicinal shrubs evaluated based on their seed germination rates at different drought levels induced by using polyethylene glycol $\left(\mathrm{PEG}_{6000}\right)$. Folia Oecologica, 48(1), 49-54. DOI: 10.2478/foecol-2021-0006.

De Carvalho, J.N., Cavalcante, M.Z.B., De Carvalho, P.A., Pifano, D.S. \& Rodrigues R.G. (2020). Ecophysiology germination of Senna uniflora seeds: species for recovery degraded areas. Journal of Seed Science, (42), e202042033. DOI: 10.1590/2317-1545v42238498.

De Souza, M.O., Pelacani, C.R., Willems, L.A.J., De Castro, R.D., Hilhorst, H.W.M. \& Ligterink W. (2016). Effect of osmopriming on germination and initial growth of Physalis angulata L. under salt stress and on expression of associated genes. An. Acad. Bras. Ciênc., 88(Suppl. 1), 503-516. DOI: 10.1590/0001-3765201620150043.

Duan, D., Liu, X., Khan, M.A. \& Gul B. (2004). Effects of salt and water stress on the seed germination of Chenopodium glaucum L. Pak. J. Bot., 36, 793-800.

Duan, D.Y., Li, W.Q., Liu, X.J., Ouyang, H. \& An P. (2007). Seed germination and seedling growth of Suaeda salsa under salt stress. Ann. Bot. Fenn., 44 161-169. https://www.jstor.org/stable/23727638.

El Ouali, L.A., El-Akhal, F., Maniar, S., Ez zoubi, Y. \& Taghzouti K. (2016). Chemical constituents and Larvicidal activity of essential oil of Lavandula stoechas (Lamiaceae) from Morocco against the malaria vector Anopheles labranchiae (Diptera: Culicidae). International Journal of Pharmacognosy and Phytochemical Research, 8(3), 505-11. DOI: 10.25258/phyto. v9i07.11173. 
El-Keblawy, A. \& Al-Rawai A. (2005). Effects of salinity, temperature and light on germination of invasive Prosopis juliflora (Sw.) DC. J. Arid Environ., 61, 555-565. DOI: 10.1016/j.jaridenv.2004.10.007

El-Keblawy, A., Al-Shamsi, N. \& Mosa K. (2018). Efect of maternal habitat, temperature and light on germination and salt tolerance of Suaeda vermiculata, a habitat-indiferent halophyte of arid Arabian deserts. Seed Sci. Res., 28(2), 140-147. DOI: 10.1017/S0960258518000144.

Ernst, M. (2017). Lavender. Lexington: Center for Crop Diversification, University of Kentucky College of Agriculture, Food and Environment https://www.uky.edu/ccd/sites/www.uky.edu.ccd/files/lavender.pdf .

Ez zoubi, Y., Bousta, D., El Mansouri, L., Boukhira, S., Siham, L., Achour, S \& Farah A. (2016). Phytochemical screening, anti-inflammatory activity and acute toxicity of hydro-ethanolic, flavonoid, Tannin and Mucilage Extracts of Lavandula stoechas L. from Morocco. International Journal of Pharmacognosy and Phytochemical Research, 8(1), 31-7. http:// impactfactor.org/PDF/IJPPR/8/IJPPR,Vol8,Issue1,Article6.pdf.

Ez zoubi, Y., Bousta, D. \& Farah A. (2020). A Phytopharmacological review of a Mediterranean plant: Lavandula stoechas L. Clinical Phytoscience, 6, 9. DOI: 10.1186/s40816-019-0142-y.

Faisal, S., Mujtaba, S.M. \& Mahboob A.W. (2019). Polyethylene Glycol mediated osmotic stress impacts on growth and biochemical aspects of whea (Triticum aestivum L.). Journal of Crop Science and Biotechnology, 22(3), 213-223. DOI: 10.1007/s12892-018-0166-0

Farooq, M., Gogoi, N., Hussain, M., Barthakur, S., Paul, S., Bharadwaj, N., Migdadi, H.M., Alghamdi, S.S. \& Siddique K.H.M. (2017). Effects, tolerance mechanisms and management of salt stress in grain legumes. Plant Physiol. Biochem., 118, 199-217. DOI: 10.1016/j. plaphy.2017.06.020.

Flowers, T.J. \& Colmer T.D. (2008). Salinity tolerance in halophytes. New Phytol., 179, 945-963. DOI: 10.1111/j.1469-8137.2008.02531.x.

Fyfield, T.P. \& Gregory P.J. (1989). Effects of temperature and water potential on germination, radicle elongation and emergence of mungbean. J. Exp. Bot., 40, 667-674. DOI: 10.1093/jxb/40.6.667.

Hossain, M., Wani, S., Bhattacharjee, S., Burritt, D. \& Tran L.S. (2016) Drought stress tolerance in plants. Vol 2. Cham: Springer. DOI 10.1007/978-3-319-32423-4.

Huang, L., Liu, X., Wang, Z., Liang, Z., Wang, M., Liu, M. \& Suarez D.L. (2017). Interactive effects of $\mathrm{pH}, \mathrm{EC}$ and nitrogen on yields and nutrient absorption of rice (Oryza sativa L). Agric. Water Manag., 194, 48-57. DOI: 10.1016/j.agwat.2017.08.012

Kanawapee, N., Sanitchon, J., Lontom, W. \& Threerakulpisut P. (2012). Evaluation of salt tolerance at the seedling stage in rice genotypes by growth performance, ion accumulation, proline and chlorophyll content. Plant Soil, 358, 235-249. DOI: 10.1007/s11104-012-1179-6.

Khan, M.A. \& Gulzar S. (2003). Germination responses of Sporobolus ioclados: a saline desert grass. J. Arid Environ., 53, 387-394. DOI: 10.1006/ jare.2002.1045.

Khan, M.A. \& Zia S. (2007). Alleviation of salinity effects by sodiumhypochlorite on seed germination of Limonium stocksii. Pak. J. Bot., 39 503-511.

Krichen, K., Ben Mariem, H. \& Chaieb M. (2014). Ecophysiological requirements on seed germination of a Mediterranean perennial grass (Stipa tenacissima L.) under controlled temperatures and water stress. S. Afr. J. Bot., 94, 210-217. DOI: 10.1016/j.sajb.2014.07.008.

Lawrence, B. (2008). A review of the world production of essential oils. Perfumer \& Flavorist 10, 1-16. https://www.perfumerflavorist.com/flavor/ rawmaterials/natural/36327094.html

Li, J., Yin, L., Jongsma, M. \& Wang C. (2011). Effects of light, hydropriming and abiotic stress on seed germination, and shoot and root growth of pyrethrum (Tanacetum cinerariifolium). Industrial Crops and Products, 34, 1543-1549. DOI: 10.1016/j.indcrop.2011.05.012.

Li, R., Shi, F. \& Fukuda K. (2010). Interactive effects of salt and alkali stresses on seed germination, germination recovery, and seedling growth of a halophyte Spartina alterniflora (Poaceae). S. Afr. J. Bot., 76, 380-387. DOI: 10.1016/j.sajb.2010.01.004

Lim, T.K. (2014). Lavandula stoechas. In: Edible Medicinal and Non Medicinal Plants. Springer, Dordrecht. DOI: 10.1007/978-94-017-8748-2_10.

Llanes, A., Reinoso, H. \& Luna V. (2005). Germination and early growth of Prosopis strombulifera seedlings in different saline solutions. World Journal of Agriculture and Soil Science, 1, 120-128. http://www.idosi.org/ wjas/wjas1(2)/4.pdf.
Ma, H., Yang, H., Lü, X., Pan, Y., Wu, H., Liang, Z. \& Ooi M.K.J. (2015). Does high $\mathrm{pH}$ give a reliable assessment of the effect of alkaline soil on seed germination? A case study with Leymus chinensis (Poaceae). Plant Soil 394, 35-43. DOI: 10.1007/s11104-015-2487-4.

Machado, R.M.A. \& Serralheiro R.P. (2017). Soil Salinity: Effect on Vegetable Crop Growth. Management Practices to Prevent and Mitigate Soil Salinization. Horticulturae, 3(2), 30. DOI: 10.3390/horticulturae3020030.

Martínez-Valderrama, J., Ibáñez, J., Del Barrio, G., Alcalá, F.J., Sanjuán,M.E., Ruiz, A., Hirche, A. \& Puigdefábregas J. (2018). Doomed to collapse: why Algerian steppe rangelands are overgrazed and some lessons to help land-use transitions. Sci. Total Environ., 613-614, 1489-1497. DOI: 10.1016/j.scitotenv.2017.07.058.

Medjebeur, D., Hannachi, L., Ali-Ahmed, S., Metna, B. \& Abdelguerfi A. (2018). Effets de la salinité et du stress hydrique sur la germination des graines de Hedysarum flexuosum (Fabaceae) (effect of salt and water stress on seed germination of Hedysarum flexuosum (Fabaceae)). Revue d'écologie (Terre et Vie), 73(3), 318-329.http://documents.irevues.inist.fr/bitstream/handle/2042/68144/RevuedEcologie_2018_73_3_318. pdf? sequence $=1$.

Mehdadi, Z., Bendimered, F.Z., Dadach, M. \& Aisset A. (2017). Effects of temperature and salinity on the seeds germination of Retama raetam (Forssk.) Webb. scarified with sulfuric acid. Journal of Fundamental and Applied Sciences, 9(3), 1284-1299. DOI: 10.4314/jfas.v9i3.3.

Michel, B.E. \& Kaufmann M.R. (1973). The osmotic potential of polyethylene glycol6000. Plant Physiol., 51, 914-916. DOI: 10.1104/pp.51.5.914.

Nedjimi, B. (2012). Rangeland improvement and management options in the arid steppes of Algeria. In M.D. Germanno (Ed.), Steppe ecosystems: dynamics, land use and conservation (pp. 157-170). New York: Nova Science Publishers.

Nedjimi, B. (2017). How $\mathrm{NaCl}, \mathrm{Na}_{2} \mathrm{SO}_{4}, \mathrm{MgCl}_{2}$ and $\mathrm{CaCl}_{2}$ salts affect the germinability of Pinus halepensis mill. Curr. Sci., 113, 2031-2035. DOI: $10.18520 / \mathrm{cs} / \mathrm{v} 113 / \mathrm{i} 10 / 2031-2035$.

Nedjimi, B., Souissi, Z.E., Guit, B. \& Daoud Y. (2020). Differential effects of soluble salts on seed germination of Marrubium vulgare L. Journal of Applied Research on Medicinal and Aromatic Plants, 17, 100250. DOI: 10.1016/j.jarmap.2020.100250

Nedjimi, B. \& Zemmiri H. (2019). Salinity Effects on Germination of Artemisia herba-alba Asso: Important Pastoral Shrub from North African Rangelands. Rangeland Ecology \& Management, 72(1), 189-194. DOI: 10.1016/j.rama.2018.07.002.

Niu, X., Bressan, R.A., Hasegawa, P.M. \& Pardo J.M. (1995). Ion homeostasis in $\mathrm{NaCl}$ stress environments. Plant Physiol., 109, 735-742. DOI: 10.1104/ pp.109.3.735.

Panuccio, M.R., Jacobsen, S.E., Akhtar, S.S. \& Muscolo A. (2014). Effect of saline water on seed germination and early seedling growth of the halophyte quinoa. AoB Plants, 6, plu047. DOI: 10.1093/aobpla/plu047.

Paraskevopoulou, A.T, Karantzi, A.K., Liakopoulos, G., Londra, P.A. \& Bertsouklis K. (2020). The Effect of Salinity on the Growth of Lavender Species. Water, 12, 618. DOI: 10.3390/w12030618.

Petit, J.R., Jouzel, J., Raynaud, D., Barkov, N.I., Barnola, J.M., Basile, I., Bender, M., Chappellaz, J., Davis, M., Delaygue, G., Delmotte, M., Kotlyakov, V.M., Legrand, M., Lipenkov, V.Y., Lorius, C., Pepin, L., Ritz, C., Saltzman, E. \& Stievenard M. (1999). Climate and atmospheric history of the past 420,000 years from the Vostok ice core, Antarctica. Nature, 399(6735), 429-436. DOI: 10.1038/20859.

Qadir, M., Ghafoor, A. \& Murtaza G. (2000). Amelioration strategies for saline soils: a review. Land Degrad. Dev., 11, 501-521. DOI 10.1002/1099-145X(200011/12)11:6\%3C501::AID-LDR405\%3E3.0.CO;2-S.

Qudir, M., Tubeileh, A., Akhtar, J., Larbi, A., Minhas, P.S. \& Khan M.A. (2008). Productivity enhancement of salt-affected environments through crop diversification. Land Degrad. Dev., 19, 429-453. DOI: $10.1002 / \mathrm{ldr} .853$

Quézel, P. \& Santa S. (1963). Nouvelle flore de l’Algérie et des régions désertiques méridionales. Paris: CNRS Press.

Rasheed, A., Hameed, A., Gul, B. \& Khan M.A. (2019). Perianth and abiotic factors regulate seed germination of Haloxylon stocksii-a cash crop candidate for degraded saline lands. Land Degrad. Dev., 30, 1468-1478. DOI: $10.1002 /$ ldr.3334.

Sarac, N. \& Ugur A. (2009). The in vitro antimicrobial activities of the essential oils of some Lamiaceae species from Turkey. Journal of Medicinal Food, 12(4), 902-907. DOI: 10.1089/jmf.2008.0089. 
Sardans, J., Urbina, I., Grau, O., Asensio, D., Ogaya, R. \& Peñuelas J. (2020) Long-term drought decreases ecosystem and nutrient storage in a Mediterranean holm oak forest. Environ. Exp. Bot., 177, 104135. DOI: 10.1016/j.envexpbot.2020.104135.

Senbayram, M., Gransee, A., Wahle, V. \& Thiel H. (2015). Role of magnesium fertilisers in agriculture: plant-soil continuum. Crop \& Pasture Science, 66, 1219-1229. DOI: 10.1071/CP15104

Shawl, A.S. \& Kumar S. (2000). Potential of Lavender oil industry in Kashmir. J. Med. Aromat. Plant Sci., 22, 319-321. https://www.cabdirect.org/cabdirect/abstract/20013071609.

Singh, S., Singh, V., Babu, GK., Kaul, V. \& Ahuja P. (2007). Economic of lavender (Lavandula officinalis L.) in Himachal Pradesh. Journal of Non- Timber Forest Products, 14, 97-100. http://ihbt.csircentral.net/id/eprint/784.

Sosa, L., Llanes, A., Reinoso, H., Reginato, M. \& Luna V. (2005). Osmotic and specific ion effects on the germination of Prosopis strombulifera. Ann. Bot., 96, 261-267. DOI: 10.1093/aob/mcil73.

Steiner, F. \& Zufo A.M. (2019). Drought tolerance of four vegetable crops during germination and initial seedling growth. BioScience Journal, 35(1), 177-186. DOI: 10.14393/BJ-v35n1a2019-41724.

Tobe, K., Li, X. \& Omasa K. (2004). Effects of five different salts on seed germination and seedling growth of Haloxylon ammodendron (Chenopodiaceae). Seed Sci. Res., 14, 345-353. DOI: 10.1079/SSR2004188.

Tuteja, N. (2007). Mechanisms of high salinity tolerance in plants. In D. Häussinger \& H. Sies (Eds.), Osmosensing and osmosignaling (pp. 419-438). San Diego: Elsevier Academic Press. DOI: 10.1016/s00766879(07)28024-3.

Ungar, I.A. (1996). Effect of salinity on seed germination, growth, and ion accumulation of Atriplex patula (Chenopodiaceae). Am. J. Bot., 83(5), 604-607. https://www.jstor.org/stable/2445919?seq=1

Vicente, M.J., Conesa, E., Álvarez-Rogel, J., Franco, J.A. \& MartínezSánchez J.J. (2009). Relationships between salt type and seed germination in three plant species growing in salt marsh soils of semi-arid Mediterranean environments. Arid Land Res. Manag., 23, 103-114. DOI: $10.1080 / 15324980902813559$.
White, P.J. \& Broadley M.R. (2003). Calcium in plants. Ann. Bot., 92, 487511. DOI: $10.1093 / \mathrm{aob} / \mathrm{mcg} 164$

Yagmur, M. \& Kaydan D. (2008). Alleviation of osmotic stress of water and salt in germination and seedling growth of triticale with seed priming treatments. African Journal of Biotechnology, 7, 2156-2162. https://www. ajol.info/index.php/ajb/article/view/58938

Yang, C., Chong, J., Li, C., Kim, C., Shi, D. \& Wang D. (2007). Osmotic adjustment and ion balance traits of an alkali resistant halophyte Kochia siev ersiana during adaptation to salt and alkali conditions. Plant Soil, 294 263-276. DOI: 10.1007/s11104-007-9251-3.

Zehra, A., Gul, B., Ansari, R., Alatar, A.A., Hegazy, A.K. \& Khan M.A. (2013). Interactive effect of salt, light and temperature on seed germination and recovery of a halophytic grass-Phragmites karka. Pak. J. Bot., 0945, 725-736.

Zeng, Y.J., Wang, Y.R. \& Zhang J.M. (2010). Is reduced seed germination due to water limitation a special survival strategy used by xerophytes in arid dunes? J. Arid Environ., 74, 508-511. DOI: 10.1016/j. jaridenv.2009.09.013.

Zhang, H., Irving, L.J., McGill, C., Matthew, C., Zhou, D. \& Kemp P. (2010) The effects of salinity and osmotic stress on barley germination rate: sodium as an osmotic regulator. Ann. Bot., 106, 1027-1035. DOI: 10.1093/ aob/mcq204.

Zhang, H., Tian, Y., Guan, B., Zhou, D., Sun, Z. \& Baskin C.C. (2018). The best salt solution parameter to describe seed/seedling responses to saline and sodic salts. Plant Soil, 426, 313-325. DOI: 10.1007/s11104-0183623-8.

Zhang, H., Zhang, G., Lü, X., Zhou, D. \& Han X. (2015). Salt tolerance during seed germination and early seedling stages of 12 halophytes. Plant Soil, 388, 229-241. DOI: 10.1007/s11104-014-2322-3.

Zhao, Y., Lu, Z. \& He L. (2014). Effects of saline-alkaline stress on seed germination and seedling growth of Sorghum bicolor (L.) Moench. Appl. Biochem. Biotechnol., 173, 1680-1691. DOI: 10.1007/s12010-014-0956-5. 